\title{
Biomass yield and fodder quality of Napier grass (Penni- setum purpureum) as affected by Pigeon pea (Cajanus cajan) intercrop and planting distance
}

\author{
E. A. TENAKWA, S. CUDJOE \& T. ANSAH* \\ (E.A.T, S.C. \& T.A.: Department of Animal Science, Faculty of Agriculture, University for \\ Development studies; P.O. Box 1882, Tamale, Ghana) \\ *Corresponding author's email: tansah@uds.edu.gh
}

\begin{abstract}
The study sought to investigate the effect of two planting distances and Pigeon Pea (Cajanus cajan) intercrop on the biomass yield, chemical composition and in vitro organic matter digestibility (IVOMD) of Napier grass (Pennisetum purpureum). The treatments were laid in a $2 \times 2$ factorial RCBD. The factors were two planting distances $(0.5 \times 0.5$ and $0.5 \times 1 \mathrm{~m})$ and two levels of intercrop (Pigeon Pea intercrop and sole Napier grass). At 90-days, the grasses were harvested and biomass yield measured. The fodder was separated into leaves and stems for chemical and digestibility analysis in $2 \times 2 \times 2$ factorial in CRD. The interaction at all levels was not significant for all the parameters. There was a significant main effect of planting distance, intercrop and botanical fraction on biomass yield, plant height, tiller number and fodder quality. Whilst biomass yield was higher $(\mathrm{P}=0.02)$ in the $0.5 \times 0.5 \mathrm{~m}$, no significant difference was recorded in the effect of the intercrop. Whilst intercrop affected $(\mathrm{P}<0.05)$ IVOMD and ME, botanical fraction significantly affected DM, CP and ME. The leaf fraction had more $(\mathrm{P}<0.05) \mathrm{DM}, \mathrm{CP}$ and ME than the stem fraction. The study revealed that close planting distance enhanced biomass yield whilst Pigeon Pea intercrop and botanical fraction affected fodder quality of Napier grass. Keywords: Cajanus cajan; crude protein; digestibility; Pennisetum purpreum; savanna zone
\end{abstract}

Original scientific paper. Received 09 Apr 18; revised 25 Sep 19

\section{Introduction}

Demand for meat and meat products as reflected in the number of animals imported and produced in Ghana continues to rise (SRID, 2014). This rise in demand requires measures that will ensure that animal production barriers are minimised to the barest minimum. Forage for livestock production has often been derived from natural sources (Ansah \& Issaka, 2018; Akapali et al., 2018), exposing quantity and quality of forage from these sources to fluctuations due to changes in climatic conditions. Increase in urbanisation and competition for land are major threats to the availability of rangelands or natural pasture for livestock production (Oba, 2013).

Napier grass (Pennisetum purpreum) has for long been an important forage crop in the tropics because of its high yields and nutritive value. According to Francis (2004),

Ghana Jnl Agric. Sci. 54 (2), 36 - 44

GJAS is an Open Access Journal and distributed under the terms of the Creative Commons (CC) License [CC BY 4.0] 
yield range from $20-80 \mathrm{tDM} / \mathrm{ha} /$ year under high fertilizer inputs. With no or inadequate fertilizer, yields are in the range of 2-10 $\mathrm{tDM} / \mathrm{ha} /$ year. With appropriate management practices, Napier grass can provide a continual supply of green forage throughout the year and best suits intensive small-scale farming systems (Orodho, 1988; Mengistu, 1997).

Pigeon pea (Cajanus cajan), is a perennial legume crop with several uses such as grain, vegetable, animal feed, green manure, and firewood (Daniel \& Ong, 1990). It can fix up to $235 \mathrm{~kg}$ Nitrogen $(\mathrm{N}) / \mathrm{ha}$ and produces more $\mathrm{N}$ per unit area from plant biomass than many other legumes. The nitrogen-fixing ability of pigeon pea is desirable for environmentally sustainable agricultural production (Peoples $e t$ al., 1995).

The importance of herbaceous forage legumes in increasing herbage production of grasses and quality of feed produced has been recognized in Kenya (Mureithi et al., 1995; Mwangi \& Wambugu, 2002). Including legume plants in fodder grasses cultivation would not only provide a nitrogen source to promote grass growth but enhance the quality of feed. Legumes benefit grasses by contributing nitrogen to the soil through atmospheric fixation, the decay of dead root nodules or mineralization of shed leaves. Haque (1986) reported that intercropping forage legumes with grasses improved feed quantity and quality. Mureithi et al. (1995) also reported improved quantity and quality of fodder in an alley farming system based on Napier grass intercropped with Leucaena in coastal lowland of Kenya.
The cultivation of Napier grass in the Northern Savanna Region of Ghana is still at the on-station level with the aim of identifying the best production system for the forage. Intercropping Napier grass with Pigeon Pea in the dry savanna zone of Ghana has not been explored. The study, therefore, sought to investigate the effect of intercrop and planting distance on the biomass yield and nutritive value of Napier grass.

\section{Materials and methods}

\section{Study Area}

This study was conducted at the Nyankpala Campus of the University for Development Studies. Geographically, the field lies within latitude $09.41001^{\circ} \mathrm{N}$ and longitude $000.98221^{\circ} \mathrm{W}$. Nyankpala is $16 \mathrm{~km}$ away from Tamale, the capital of the region at an altitude of $167 \mathrm{~m}$ above sea level. The mean annual rainfall of the area is $1043 \mathrm{~mm}$ distributed fairly from April to late November. Temperatures generally fluctuate between $15^{\circ} \mathrm{C}$ (minimum) and $42^{\circ} \mathrm{C}$ (maximum) with a mean annual temperature of $28.5^{\circ} \mathrm{C}$. The mean annual day time relative humidity is $54 \%$. The terrain of the area is somewhat flat with the soil type being sandy-loam.

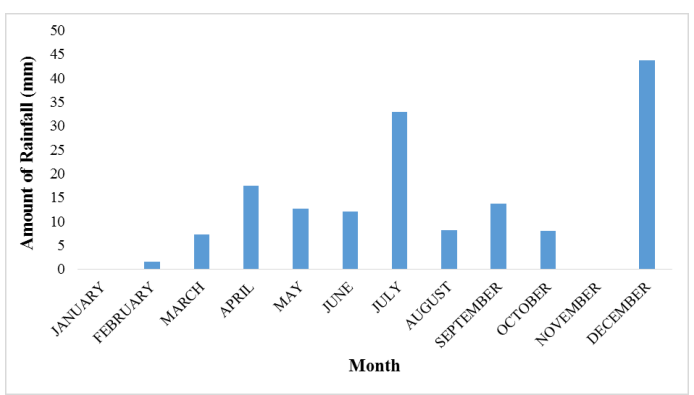

Fig. 1: Amount of Rainfall in 2016 in the study area 


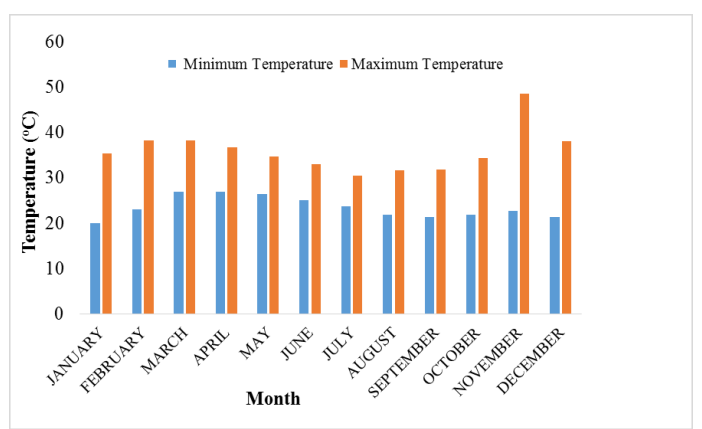

Fig. 2: Temperature Range of study area in 2016

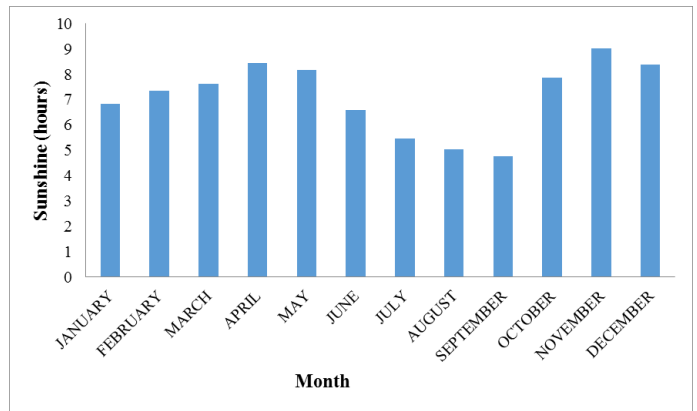

Fig. 3: Duration of Sunshine in the study area in 2016

\section{Source of Planting Materials}

The local variety of Napier grass commonly found growing in Techiman in the Brong Ahafo region of Ghana was selected for this study due to its high yield and tolerance to the climatic condition in the dry Savana Region (Cudjoe, 2017).

\section{Experimental land preparation and layout and planting}

The field was ploughed and divided into 16 plots with each measuring $15 \mathrm{~m}^{2}(5 \mathrm{~m} \times 3 \mathrm{~m})$.

The parent plant was cut into stems with a minimum of three nodes per cutting for planting and was planted $15-20 \mathrm{~cm}$ deep at an angle of about $30^{\circ}-45^{\circ}$ in the ground. There were four treatments with three replicates each laid in a $2 \times 2$ factorial in randomized complete block design. The factors were two levels of planting distance $(0.5 \times 0.5 \mathrm{~m}$ and $1 \times 0.5$ $\mathrm{m}$ ) and two levels of intercrop (Pigeon pea $\mathrm{x}$ Napier intercrop and sole Napier grass).

\section{Plant management and data collection}

Weeding was carried out on the third and sixth weeks after planting. Compound fertilizer (NPK) was applied 21 days after planting at a rate of $60 \mathrm{~kg} / \mathrm{ha}$. The fertilizer was surfaced applied using the side placement technique.

\section{Plant height and tiller number}

Five plants were selected from each plot randomly excluding those on the borders. Plant height and tiller numbers were measured weekly after 21 days post-planting. Plant height was measured from the base of the tiller to the tip of the selected leaf and tiller number was measured by simple arithmetic counting.

\section{Harvesting and herbage yield}

The grasses were harvested 90 days after planting using a machete and the total harvest per plot weighed. Approximately $200 \mathrm{~g}$ of sub-sample was taken from each plot and chopped into short lengths $(2-5 \mathrm{~cm})$ for dry matter determination using the AOAC (1990) procedure. This involves drying in an oven at $60^{\circ} \mathrm{C}$ for 48 hours. Herbage yield of each plot was calculated on a dry matter basis by multiplying the percentage dry weight of the sub-samples from the whole fraction to the fresh weight of the harvest from each plot.

\section{Chemical analysis and in vitro digestibility}

The harvested grass was further subjected to feed quality assessment. The design was the $2 \mathrm{x}$ $2 \times 2$ factorial in randomized complete design. The factors were two planting distances $(0.5$ 
x $0.5 \mathrm{~m}$ and $1 \times 0.5 \mathrm{~m}$ ), two legume intercrop (Pigeon pea + Napier and sole Napier grass) and two botanical fractions (leaf and stem).

About 10 whole plants from each plot were separated into leaves and stems by hand to represent the two botanical fractions. The fractions were dried at $60^{\circ} \mathrm{C}$ for 48 hours and ground using a laboratory mill to pass through $1 \mathrm{~mm}$ sieve screens for laboratory analysis.

The AOAC (1990) procedure was used in the determination of dry matter (DM), crude protein (CP) and ash. The method of Van Soest et al. (1991) was used to determine neutral detergent fibre (NDF) and acid detergent fibre (ADF) and was analysed using the Ankom ${ }^{200}$ fibre analyser (Method 5 and Method 6).

The in vitro gas production technique of Theodorou et al. (1994) was adopted with some modification in the source of rumen fluid (Ansah et al., 2016; Ansah et al., 2018) to estimate the 24 hours gas production which was then used to compute the organic matter digestibility and metabolizable energy. In vitro organic matter digestibility (IVOMD) was calculated using the equation IVOMD (\%) $=16.49+0.9042 * G P+0.0492 * C P+$ $0.0387^{*}$ ash of Menke and Steingass (1988), while metabolizable energy was calculated using the equation: $M E(M J / k g D M)=2.20+$ $0.136 * G P+0.057 * C P$ according to Menke et al. (1979), where: $\mathrm{GP}=$ gas production $(\mathrm{ml} / 200$ $\mathrm{mg} \mathrm{DM}$ at 24 hours) and $\mathrm{CP}=$ crude protein (g/ $\mathrm{kg} \mathrm{DM})$.

\section{Statistical Analysis}

All data collected were subjected to analysis of variance using GenStat Statistical package, 12th edition (Payne et al., 2008). Means were separated using Least Significant Difference (LSD) when F-test was significant at 5\%.

\section{Results and discussion}

The effects of planting distance and legume intercrop interaction were not significant. There was a significant main effect of planting distance on biomass yield of Napier grass with a higher yield $(3143.0 \mathrm{~kg} / \mathrm{ha})$ recorded in the closer $(0.5 \times 0.5 \mathrm{~m})$ planting distance. The results agree with the findings of Wijitphan et al. (2009) who reported higher yield for Napier grass planted with similar planting distance. The difference in yield may be attributed to the higher plant population in the close planting distance. Nonetheless, Hamidia et al. (2010) suggested that progressively yield of closely spaced grasses decline as harvesting days prolong due to competition. Harvesting Napier grass planted at $0.5 \times 0.5 \mathrm{~m}$ at 90 days appears to be adequate to secure a higher yield in the savanna zone of Ghana.

The effect of intercropping Napier grass with Pigeon Pea was not significant. This finding differs from what was reported by Mureithi et al. (1995) and Anantawiroon et al. (2006) who all found significant effect of legume intercrop on the yield of Napier grass. The biomass yield recorded for both treatments were similar to what was reported by Cudjoe (2017) in the savanna zone but was lower than what was reported by Ansah et al. (2010) in the humid zone of Ghana.

The Pigeon Pea intercrop resulted in taller Napier grasses than the sole Napier (2.5 $\mathrm{m}$ vs $1.7 \mathrm{~m}$ ). The Napier grass in the intercrop may have benefited from the available nitrogen fixed by the legumes.

Plant spacing did not affect plant height and this agrees with the findings of Tilahun et al. (2017). Generally, the plant height was comparable to what was reported by Cudjoe (2017) in the savanna zone but lower than what was reported by Ansah et al. (2010) in the humid zone. 
TABLE 1

Mean effect of planting distance and legume intercrop on agronomic parameters of Napier grass

\begin{tabular}{cccccccc}
\hline \multirow{3}{*}{ Parameter } & \multicolumn{4}{c}{ Treatment } & Sed & \multicolumn{2}{c}{ P. value } \\
\cline { 2 - 5 } & \multicolumn{2}{c}{$0.5 \times 0.5 M$} & \multicolumn{2}{c}{$1 \times 0.5 M$} & & \multirow{2}{*}{ Distance } & \multirow{2}{*}{ Intercrop } \\
\cline { 2 - 5 } & Intercrop & Sole & Intercrop & Sole & & & \\
\hline Biomass yield (kg/ha) & 2839 & 3446 & 1742 & 2154 & 616.8 & 0.02 & 0.27 \\
Plant height (m) & 2.17 & 1.75 & 2.86 & 1.73 & 0.12 & 0.07 & 0.003 \\
Tiller number & 9.83 & 7.19 & 8.43 & 7.13 & 1.42 & 0.47 & 0.05 \\
\hline
\end{tabular}

The intercrop with Pigeon Pea significantly increased the tiller number of Napier grass than the sole grass (9.1 vs 7.2). This can be attributed to a probably high uptake of nitrogen supplied by the legume. Wolfson (1989) reported increased tiller number in grass planted with high nitrogen supply. The weekly tiller number of the Napier grass as influenced by the legume intercrop and planting distance is shown in Fig. 3. Sole Napier grass increased in tiller number after the 7 th week till the 13 th week. The closer planting distance was also higher in tiller number from the 4th week through to the 13th week with the margin of increase being wider between the 6 th and the 10 th week.

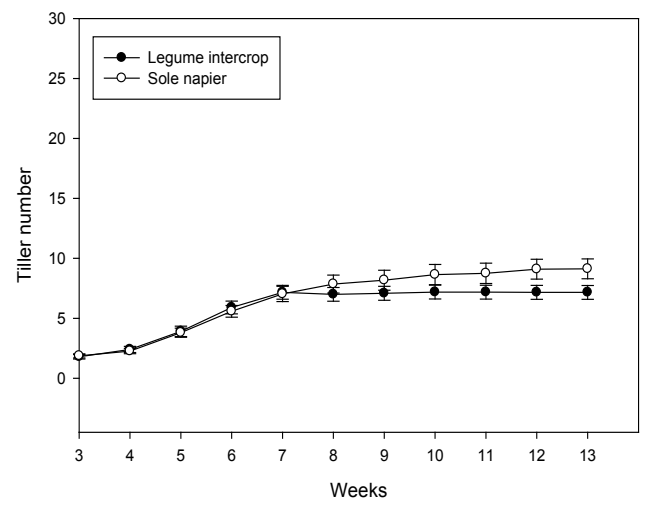

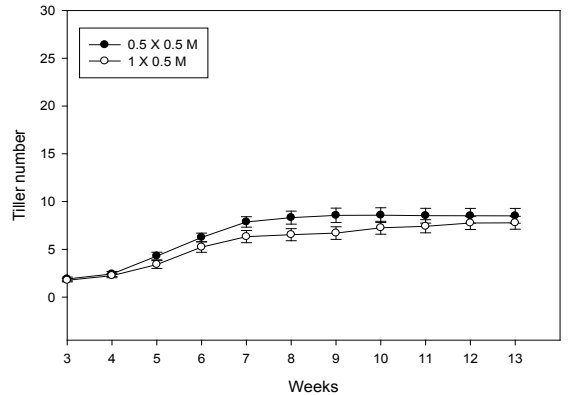

Fig.3: Mean weekly tiller number of Napier grass as affected by legume intercrop and planting distance.

Weekly plant height increased throughout the growth period for both treatments. Legume intercrop led to a higher margin of increase in plant height after the 8 th week to the end of the growth period. On the other hand, Napier grass in the closer planting distance treatment had a higher plant height compared to the wider distance throughout the growth period (Fig. 5). 

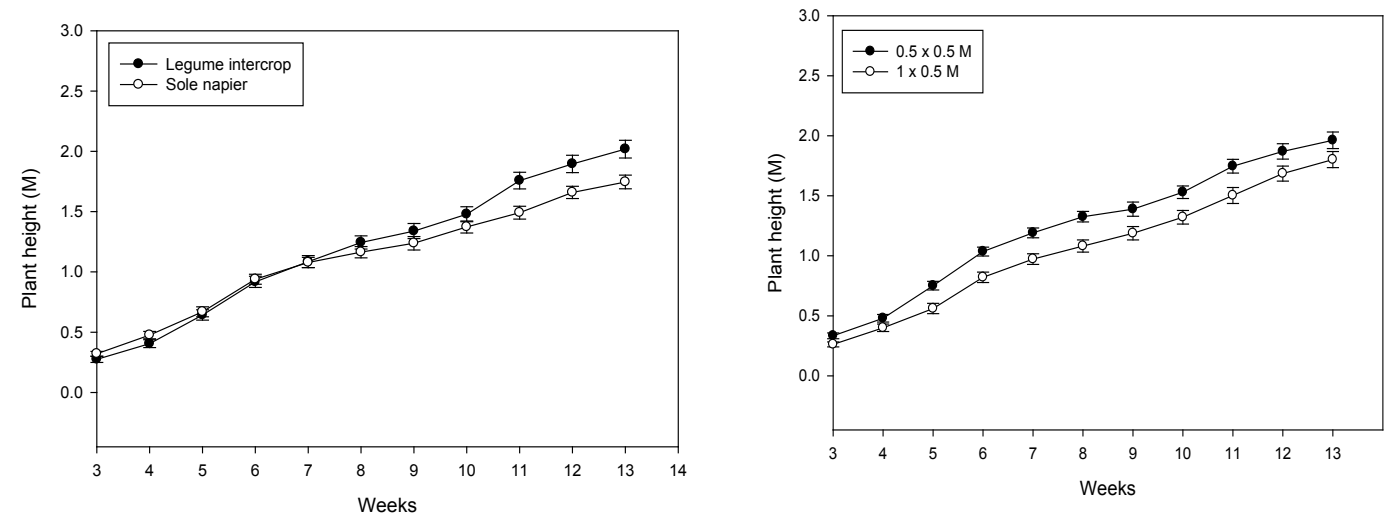

Fig. 4: Mean weekly plant height of Napier grass as affected by legume intercrop and planting distance

Effect of planting distance, botanical fraction and legume intercrop on the nutritive value of Napier grass

Both three-way and two-way interaction of planting distance, legume intercrop and botanical fraction did not have significant effect on the nutritive value parameters (Table $2)$. The $\mathrm{CP}$ concentration was higher $(\mathrm{P}<0.05)$ in the leaf than stem fraction. This agrees with the finding of Tang et al. (2008) and Ansah et al. (2010) who all reported higher CP in leaf than the stem of grass. As grass matures, $\mathrm{CP}$ content decreased in the whole plant, but this has been found to be more rapid in the stem than in the leaves (Achakzi et al., 2007; Ansah et al., 2010). The CP concentration was lower than the requirement (110 to $130 \mathrm{~g} / \mathrm{kg}$ ) for the maintenance of small ruminants (NRC, 2007) suggesting that protein supplementation will be required when Napier grass is fed ruminants.

TABLE 2

Mean chemical composition $(\mathrm{g} / \mathrm{kg}$ DM), digestibility and metabolizable energy of Napier grass as influenced by planting distance, legume intercrop and botanical fraction.

\begin{tabular}{|c|c|c|c|c|c|c|c|c|c|c|c|c|}
\hline \multirow{4}{*}{ Parameter $(g / k g D M)$} & \multicolumn{9}{|c|}{ Treatment } & \multirow{2}{*}{\multicolumn{3}{|c|}{ P. value }} \\
\hline & \multicolumn{4}{|c|}{$0.5 \times 0.5 \mathrm{M}$} & \multicolumn{4}{|c|}{$1 \times 0.5 \mathrm{M}$} & \multirow{3}{*}{-S.e.d } & & & \\
\hline & \multicolumn{2}{|c|}{ Intercrop } & \multicolumn{2}{|l|}{ Sole } & \multicolumn{2}{|c|}{ Intercrop } & \multicolumn{2}{|l|}{ Sole } & & \multirow{2}{*}{ Distance } & \multirow[b]{2}{*}{ Intercrop } & \multirow[b]{2}{*}{ Fraction } \\
\hline & Leaf & Stem & Leaf & Stem & Leaf & Stem & Leaf & Stem & & & & \\
\hline$\overline{\mathrm{DM}}$ & 224.1 & 122.1 & 243.2 & 128.6 & 248.1 & 119.6 & 237.2 & 138.6 & 14.0 & 0.37 & 0.24 & $<0.001$ \\
\hline $\mathrm{CP}$ & 75.3 & 42.2 & 73.8 & 40.7 & 83.4 & 47.9 & 63.0 & 46.0 & 7.7 & 0.59 & 0.24 & $<0.001$ \\
\hline NDF & 619.8 & 646.2 & 636.4 & 635.5 & 631.9 & 633.8 & 628.8 & 628.6 & 13.8 & 0.59 & 0.93 & 0.33 \\
\hline $\mathrm{ADF}$ & 399.1 & 422.4 & 417 & 403 & 384.3 & 383.8 & 391.1 & 395.1 & 11.6 & 0.001 & 0.48 & 0.59 \\
\hline Ash & 140.1 & 142.2 & 141.5 & 133.4 & 140.9 & 143.9 & 142.1 & 135.3 & 9.6 & 0.79 & 0.44 & 0.61 \\
\hline IVOMD (\%) & 40.6 & 39.8 & 30.4 & 30.2 & 38.9 & 41.2 & 29.5 & 30.2 & 1.0 & 0.60 & $<0.001$ & 0.34 \\
\hline $\mathrm{ME}(\mathrm{MJ} / \mathrm{kg})$ & 8.8 & 7.4 & 7.2 & 5.4 & 9.0 & 7.5 & 6.4 & 5.8 & 0.4 & 0.90 & $<0.001$ & $<0.001$ \\
\hline
\end{tabular}

CP: crude protein, DM: dry matter, NDF: neutral detergent fibre, ADF: acid detergent fibre, IVOMD: in vitro organic matter digestibility, ME: metabolizable energy, P: 0.05. 
Planting distance significantly affected ADF concentration with the highest concentration recorded in the closer planting distance. Tilahun et al. (2017) did not find significant effect of plant spacing on ADF concentration in Napier grass, even though, the values reported were similar. Increasing dietary ADF has been found to reduce voluntary feed intake (Gusha et al. 2015) and this can affect the efficient utilization of the nutrients in the closely spaced plants.

Napier grass intercropped with Pigeon Pea had a higher $(\mathrm{P}<0.01)$ mean IVOMD and ME compared to the sole Napier. Similar effects were reported by Njoka- Njiru et al. (2006) and Bayble et al. (2007) when Napier grass intercropped with legume was compared with sole Napier. The lower IVOMD in the sole Napier may have been influenced by the relatively higher mean ADF (410 vs 309) recorded for the same treatment. Increasing cell wall carbohydrate has been reported to cause a decline in the digestibility of forages (Van Soest, 1994). The IVOMD and ME were comparable to what was reported by Cudjoe (2017) for the same variety in a previous study. However, the IVOMD was below $50 \%$ and therefore may require supplementation during feeding to enhance the digestibility. Botanical fraction significantly affected ME with the leaf fractions having superiority over the stem fraction.

\section{Conclusion and recommendation}

Whilst biomass yield was higher in the closely planted Napier grass, the legume intercrop did not have an effect after 90 days. Plant height and tiller number all appreciated in the legume intercrop compared to the sole Napier grass. Dry matter, crude protein and metabolizable energy were all higher in the leaf fraction than the stem fraction. The organic matter digestibility and Metabolizable energy were also higher in the legume intercrop than the sole Napier grass.

Even though intercropping Napier grass with Pigeon Pea did not influence yield, its effect on quality makes its use in Napier production very important since it has the potential of enhancing animal productivity. Most nutrients were stored in the leaf fraction and therefore leaf losses during utilization or storage should be minimized in order to ensure optimum benefit for the animals.

\section{REFERENCES}

Akapali, M., Ansah, T., Abdul-Rahman, I.I., Alenyorege, B. \& Baatuuwie, B.N. (2018) Seasonal changes in pasture biomass and grazing behaviour of cattle in the Guinea Savanna agroecological zone of Ghana, African Journal of Range \& Forage Science. doi: 10.2989/10220119.2018.1480526

Achakzai, A. K. K. \& Panizai, K. (2007) Effect of row spacing on growth, yield and yield components of mashbean. Sarhad Journal of Agriculture 23 (1), 5.

Anantawiroon, P., Tudsri, S. \& Ishit, Y. (2006) The effect of intercropping with four tropical legume species on the yield and quality of Napier grass in Thailand. Kasetsart Journal of Natural Science 40, 616 - 624.

Ansah, T. \& Issaka, C. A. (2018) Ruminant livestock feed resources in the kumbungu district of Ghana. Ghanaian Journal of Animal Science $9(1)$.

Ansah, T., Algma, H. A. \& Dei, H. K. (2016) Variety and phosphate fertilizer dose effect on nutrient composition, in vitro digestibility and feeding value of cowpea haulm. Journal of animal science and technology 58 (1), 19. 
Ansah, T., Osafo, E. L. K. \& Hansen, H. H. (2010) Herbage yield and chemical composition of four varieties of Napier (Pennisetum purpureum) grass harvested at three different days after planting. Agriculture and Biology Journal of North America 1 (5), 923 - 929.

AOAC (1990) Official methods of analysis of Association of Official Analytical Chemists (16th edition), Washington, DC.

Bayble, T., Melaku, S. \& Prasad, N. K. (2007) Effects of cutting dates on nutritive value of Napier (Pennisetum purpureum) grass planted sole and in association with Desmodium (Desmodium intortum) or Lablab (Lablab purpureus). Livestock Research for Rural Development 19 (1), 120 - 136.

Cudjoe, S. (2017) Fodder yield and quality of four elephant grass varieties planted in the dry savanna region of Ghana. M.Phil. Thesis Department of Animal Science, University for Development Studies, Ghana.

Daniel, J. N. \& Ong, C. K. (1990) Perennial pigeon pea: a multi-purpose species for agroforestry systems. Agroforestry Systems 10 (2), 113 129.

Francis, J. K. (2004) Wildland shrubs of the United States and its Territories: thamnic descriptions: volume 1. General Technical Report-International Institute of Tropical Forestry, USDA Forest Service, (IITF-GTR-26).

Gusha, J., Halimani, T. E., Ngongoni, N. T. \& Ncube, S. (2015) Effect of feeding cactus-legume silages on nitrogen retention, digestibility and microbial protein synthesis in goats. Animal Feed Science and Technology 206, pp. 17.

\section{Hamidia, A., Khodabandehb, N. \& Mohammady-} nasabc, A. D. (2010) Plant density and nitrogen effects on some traits of maize (Zea mays L.). Plant Ecophysiol 2, $47-52$.

Haque, I. (1986) Potentials of Forage Legumes in Farming Systems of Sub-Saharan Africa: Proceedings of a Workshop Held at ILCA, Addis
Ababa, Ethiopia, 16 - 19 September 1985. ILRI (aka ILCA \& ILRAD).

Mengistu, A. (1997) Conservation-based forage development for Ethiopia. Conservation-based forage development for Ethiopia.

Menke, K. H. \& Steingass, H. (1988) Estimation of the energetic feed value obtained from chemical analysis and in vitro gas production using rumen fluid. Animal Research and Development 28, $7-55$.

Menke, K. H., Raab, L., Salewski, A., Steingass, H., Fritz, D. \& Schneider, W. (1979) The estimation of the digestibility and metabolizable energy content of ruminant feeding stuffs from the gas production when they are incubated with rumen liquor in vitro. The Journal of Agricultural Science 93 (1), 217 - 222.

Mureithi, J. G., Tayler, R. S. \& Thorpe, W. (1995) Productivity of alley farming with leucaena (Leucaena leucocephala Lam. de Wit) and $\mathrm{Na}-$ pier grass (Pennisetum purpureum K. Schum) in coastal lowland Kenya. Agroforestry Systems 31 (1), 59 - 78.

Mwangi, D. M. \& Wambugu, C. (2002) Forage legume technologies: Participatory experiences with farmers and community-based organisations in Central Kenya. Smallholder dairy production and marketing-Opportunities and constraints $\mathbf{4 6 9}$.

Njoka-Njiru, E. N., Njarui, M. G., Abdulrazak, S. A. \& Mureithi, J. G. (2006) Effect of intercropping herbaceous legumes with Napier grass on dry matter yield and nutritive value of the feedstuffs in semi-arid region of eastern Kenya. Agricultura Tropica Et Subtropica 39 (4).

National Research Council (NRC) (2007) Nutrient requirements of small ruminants: Sheep, goats, Cervids and New World Camelids. National Academy of Science, Washington, DC. pp 347. 
Oba G. (2013) The sustainability of pastoral production in Africa. In: Catley A, Lind J, Scoones I (eds), Pastoralism and development in Africa: dynamic

Orodho, A. B. (1988) Dissemination and utilisation of research technology on forages and agricultural by-products in Kenya. In Utilization of research results on forage and agricultural by-product materials as animal feed resources in Africa. Proceedings of the first joint workshop held in Lilongwe, Malawi, 5 - 9.

Payne, R.W., Murray, D.A., Harding, S.A., Baird, D.B. \& Soutar, D.M. (2008) GenStat for Windows (12th Edition) Introduction. VSN International, Hemel Hempstead. pp. 204.

Peoples, M. B., Herridge, D. F. \& Ladha, J. K. (1995) Biological nitrogen fixation: an efficient source of nitrogen for sustainable agricultural production? Plant and soil 174 (1 2), $3-28$.

SRID (2014) Agriculture in Ghana. Facts and Figures. Statistical Research and Information Directorate, Ministry of Food and Agriculture, Accra, Ghana.

Tang, S. X., Gan, J., Sheng, L. X., Tan, Z. L., Tayo, G. O., Sun, Z. H. \& Ren, G. P. (2008) Morphological fractions, chemical composition and in vitro fermentation characteristics of maize stover of five genotypes. Journal of Animal Science 12 (2), $1772-1779$.
Theodorou, M. K., Williams, B. A., Dhanoa, M. S., McAllan, A. B. \& France, J. A. (1994) Simple gas production method using a pressure transducer to determine the fermentation kinetics of ruminant feeds. Animal Feed Science Technology 48, 185 - 197.

Tilahun, G., Asmare, B. \& Mekuriaw, Y. (2017) Effects of harvesting age and spacing on plant characteristics, chemical composition and yield of desho grass (Pennisetum pedicellatum Trin.) in the highlands of Ethiopia. Tropical Grasslands-Forrajes Tropicales 5 (2),77 - 84

Van Soest, P. J. (1994) Nutritional ecology of the ruminant. Cornell University Press.

Van Soest, P. J., Robertson, J. B. \& Lewis, B. A. (1991) Methods for dietary fiber, neutral detergent fiber, and nonstarch polysaccharides in relation to animal nutrition. Journal of dairy science 74 (10), 3583 - 3597.

Wijitphan, S., Lorwilai, P. \& Arkaseang, C. (2009) Effects of plant spacing on yields and nutritive values of Napier grass (Pennisetum purpureum Schum.) under intensive management of nitrogen fertilizer and irrigation. Pakistan Journal of Nutrition 8 (8), 1240 - 1243.

Wolfson, M.M. (1989) The effect of inorganic nitrogen on growth, morphology of Digitaria eriantha (Steud). PhD thesis. University of the Wiwatersrand, Johannesburg. 